\title{
Phototesting and photoprotection in LE
}

M. Walchner, G. Messer and P. Kind

Lupus 1997 6: 167

DOI: 10.1177/096120339700600212

The online version of this article can be found at:

http://lup.sagepub.com/content/6/2/167

\author{
Published by: \\ (S)SAGE \\ http://www.sagepublications.com
}

Additional services and information for Lupus can be found at:

Email Alerts: http://lup.sagepub.com/cgi/alerts

Subscriptions: http://lup.sagepub.com/subscriptions

Reprints: http://www.sagepub.com/journalsReprints.nav

Permissions: http://www.sagepub.com/journalsPermissions.nav

Citations: http://lup.sagepub.com/content/6/2/167.refs.html

>> Version of Record - Jan 1, 1997

What is This? 


\title{
Phototesting and photoprotection in LE
}

\author{
M Walchner, G Messer and P Kind \\ Department of Dermatology, Ludwig-Maximilians-University of Munich, Frauenlobstraße 9-11, D-80337 Munich, Germany
}

\begin{abstract}
Photosensitivity and induction of skin lesions following UV radiation is a common problem of patients with cutaneous and systemic forms of lupus erythematosus. The detrimental effect of UV radiation to patients with lupus erythematosus was already recognized in the last century. Skin lesions can now be provoked under standardized conditions allowing the diagnosis and classification of patients with photosensitive disorders. The aim of this review is to give an overview on the history, test procedure and test results in patients with lupus erythematosus.
\end{abstract}

Keywords: phototesting; photosensitivity; lupus erythematosus; photoprotection

\section{Introduction}

Lupus erythematosus (LE) develops due to reduction of tolerance against self. Systemic and cutaneous forms can be distinguished according to clinical, histological and immunologic parameters. Among these are systemic lupus erythematosus ${ }^{1,2}$ (SLE), subacute cutaneous lupus erythematosus ${ }^{3-5}$ (SCLE), lupus erythematosus tumidus ${ }^{6}$ (LET), lupus erythematosus profundus ${ }^{7,8}$ (LEP), chronic discoid lupus erythematosus ${ }^{8,9}$ (CDLE) and disseminated discoid lupus erythematosus. ${ }^{10}$ (DDLE). Cutaneous lesions tend to occur in sun-exposed areas of the skin and can be reproduced experimentally. Photosensitivity is common in LE patients. Our own investigations on 189 patients revealed that almost every second patient with systemic or generalized forms of LE (SLE: 48\%; SCLE: $49 \%$, DDLE: $45 \%$, LET: $43 \%$ ) and approximately every forth patient with cutaneous disease (DLE: 25\%) reported photosensitivity. Phototesting with standardized protocols, however, demonstrated that these percentages differ ${ }^{11,12}$ (SLE: 35\%, SCLE: 63\%, LET: $81 \%$, DLE: $36 \%$ ). One of the reasons for the divergent data between the reported and tested photosensitivity may be the fact that skin lesions following UV radiation do not develop rapidly after a few hours like sunburn reaction, but appear after two to three weeks. Therefore, a relationship between sun exposure and exacerbation of LE does not seem obvious to the patient.

UV-induced skin damage in general depends on the quality and quantity of UV radiation. Photons, packages of energy, have a defined energy depending on the wavelength and frequency. The energy of a

Correspondence: Dr M Walchner. photon is inversely related to the wavelength and directly related to the frequency. When light meets the outer surface of the skin it is partially reflected depending on the surface. The absorbed part of the light energy reaches deeper layers. The penetration depends on the refractive index of each tissue. Almost all of the UVB radiation is absorbed in the first $0.3 \mathrm{~mm}$ of normal skin, whereas practically all of visible light penetrates into the subcutis. Generally said, the longer the wavelength the deeper the penetration. This is partly due to absorption of higher light energy by chromophores contained in the outer layers.

The first step of a photoinduced skin reaction is the absorption of photons by chromophores leading to the formation of photoproducts. Cells of the dermis, epidermis, and subcutis contain chromophores such as DNA, RNA, proteins, porphyrins and lipids. DNA is mainly affected by electromagnetic waves between 250 and $300 \mathrm{~nm}$, since the absorption spectra of pyrimidines and purines are within these wavelengths. ${ }^{13}$ Proteins contain cyclic molecules such as aromatic (tyrosine, phenylalanine) and heterocyclic (tryptophane, histidine) amino acids. After activation by UV rays chromophores become unstable and by releasing energy return back to their original energy stage. Energy is then transferred to secondary molecules and formation of reactive oxygen intermediates (ROI) follows. ${ }^{14}$ These molecules are central mediators of cell activation leading to gene expression and synthesis of proteins, such as pro-inflammatory cytokines. ${ }^{15}$ Concerning lupus erythematosus it was shown that UVA and UVB irradiation induces stronger accumulation of ROI in murine SLE-derived spleen cells compared to controls. ${ }^{16}$

After the initiation several steps follow, in general leading to upregulation of cell membrane proteins, 
translocation of intracellular proteins, apoptosis, disappearance of Langerhans cells and formation of inflammatory infiltrates. Cytokines released by keratinocytes are important mediators of skin reactions following UV radiation. ${ }^{17-19}$ One of these cytokines dominant in contact hypersensitivity and UV-induced skin reactions is tumor necrosis factor (TNF)- $\alpha$. The TNF- $\alpha$ and $-\beta$ promoters contain UV-responsive elements, for example recognition sequences binding the nuclear factor (NF)- $k \mathrm{~B}$, which is indirectly activated by ROI. ${ }^{15,20,21}$ Genetic polymorphisms may furthermore predispose to enhanced photosensitivity, for example a promoter/enhancer polymorphism of TNF- $\alpha$ is significantly associated with enhanced TNFsecretion levels upon stimulation (Mayer et al, personal communication) and with photosensitivity in SCLE patients (Schmidt et al, personal communication). Other cytokines like IL-1, IL-3 and TGF- $\beta$ are also important mediators of inflammatory skin reactions. ${ }^{22,23}$ Once generated, binding of autoantibodies against structures on the celluar surface may then lead to antibody dependent cell cytotoxicity and destruction. ${ }^{24-27}$ Histologically basement membrane thickening, deposition of immunoglobulins and complement factors, atrophy of the pilosebaceous apparatus, lymphocytic infiltrates, hyperkeratosis and epidermal cell necrosis can be found to varying degrees in cutaneous and systemic forms of LE. ${ }^{28-33}$

It is generally accepted that photodamage in CDLE patients is restricted to local tissue and not observed in sun-protected areas, whereas this restriction is not the case in SLE patients. Here, even exacerbation of systemic disease may follow UV radiation. In various mouse models with increased susceptibility for the development of SLE-like disease it was shown that mainly UVB radiation in vivo caused increased mortality and accelerated the development of autoimmune responses. ${ }^{34,35}$ The data concerning UVA radiation, however, are still controversial. ${ }^{36}$ In an attempt to standardize conditions leading to photoinduced skin lesions phototests were established.

\section{History}

In 1851 Cazenave suggested the term 'lupus erythematosus' (LE) for a disease characterized by red spots and thinning of the skin on cheeks and ears with a chronic course. He observed that it could spread to the body and appeared in most patients without harm to general health. ${ }^{37}$ Cold air or fire were suspected trigger factors. Despite an excellent description of systemic and cutaneous forms of LE Kaposi supposed factors like local seborrhea and hormones, but not UV radiation, leading to an inflammation of the sebaceous glands. ${ }^{38}$ Only some years later a possible role of the sunlight in development of LE was recognized. ${ }^{39}$ Several publications followed demonstrating the effect of sunlight on LE and the increased incidence in the months of spring. ${ }^{40-42}$ These observations led to the conclusion that LE belongs to the group of photoaggravated diseases 'occuring as Koebner phenomenon'. ${ }^{43}$

The first intended photoprovocation of two LE patients was probably performed by Jesionek published in the 'modern guide lines of light therapy' in

Table 1 Phototesting in LE

\begin{tabular}{|c|c|c|c|c|c|c|}
\hline \multirow[b]{2}{*}{ Year } & \multicolumn{4}{|c|}{ Positive test reaction } & \multirow[b]{2}{*}{ Comment } & \multirow[b]{2}{*}{ Reference } \\
\hline & $\begin{array}{l}S L E \\
n=\end{array}$ & $\begin{array}{l}D L E \\
n=\end{array}$ & $\begin{array}{l}S C L E \\
n=\end{array}$ & $M E D$ & & \\
\hline 1916 & & $2 / 2$ & & ? & First report on reproducible skin lesions after UV treatment of LE patients with tuberculosis & [44] \\
\hline 1938 & & $1 / 1 ?$ & & $?$ & Beneficial effect of oral quinine following provocation & [45] \\
\hline 1948 & $5 / 8$ & & & ? & Favorable effect of para-amino-benzoic acid & [46] \\
\hline 1949 & & & $1 / 1 *$ & ? & Beneficial effect of sunscreen & [47] \\
\hline 1965 & $4 / 21$ & $1 / 4$ & & $?$ & $\begin{array}{l}\text { First study, reactions occurred after weeks, no induction of lesions by using UVA } \\
\text { Note: systemic immunosuppressive treatment in } 14 / 21 \text { and } 2 / 4 \text { of LE patients }\end{array}$ & [48] \\
\hline 1965 & $0 / 5$ & $0 / 23$ & $1 / 1^{*}$ & $2-3 ?$ & Induction of systemic reaction possible. Note: follow up of one week & [49] \\
\hline 1967 & $4 / 5$ & $4 / 9$ & - & $5-10$ & Intradermal hydroxychloroquine blocks reaction, possible association with antinuclear factors & [54] \\
\hline 1969 & & $8 / 10$ & & 8 & $\begin{array}{l}\text { Possible block of positive reactions by systemic quinacrine. Important wavelength } 300 \mathrm{~nm} \text {, } \\
\text { MED normal in LE patients }\end{array}$ & [51] \\
\hline 1973 & & $6 / 6$ & & $8-13$ & $\begin{array}{l}\text { Different wavelengths tested }(250-330 \mathrm{~nm}), 330 \mathrm{~nm} \text { may induce lesions in } 3 / 6 \text {. Disseminated } \\
\text { DLE more photosensitive }\end{array}$ & [52] \\
\hline 1974 & $8 / 20$ & $5 / 12$ & & $10 \times 6$ & All patients have more cytoplasmic tubular aggregates after UV radiation & [73] \\
\hline 1989 & $6 / 7$ & $7 / 9$ & $7 / 8$ & 2 & Testing of different wavelengths, also UVA and visible light can induce lesions & {$[61]$} \\
\hline 1990 & $11 / 36$ & $1 / 20$ & $6 / 14$ & $3 \times 1.5$ & UVA induces skin lesions & {$[60]$} \\
\hline 1991 & $37 / 50$ & $18 / 29$ & $35 / 35$ & 2 & MED lower in LE patients & [74] \\
\hline 1993 & $6 / 23$ & & & - & UVA and SLE & [75] \\
\hline 1993 & see $[60]$ & & & $3 \times 1.5$ & LE tumidus very photosensitive ( $22 / 32$ patients) & [12] \\
\hline 1996 & $8 / 20$ & $11 / 28$ & $11 / 20$ & $3 \times 1.5$ & Phototest with UVA, UVB, UVA-UVB & this report \\
\hline
\end{tabular}

*Clinical data resemble SCLE [4]. 
$1916^{44}$ (Table 1). He claimed to be able to reproduce skin lesions by the use of light. Years later Davidson observed development of skin lesions in a LE patient following UV radiation with a quartz lamp for the treatment of tuberculosis and noted the beneficial effect of oral administration of quinine in the treatment of $\mathrm{LE}^{45}$ A decade later Zarafonetes observed five out of eight patients who were hypersensitive to tests with ultraviolet light. ${ }^{46}$ In this series he also noted a favorable protection of paraaminobenzoate as a form of chemical sunscreen. Also Garzon et $a l^{47}$ was able to reproduce skin lesions in a patient with subacute lupus erythematosus, probably a patient with SCLE. In parallel he demonstrated the beneficial effect of sunscreens.

Early clinial studies for testing photosensitivity of LE patients were performed by the groups of Epstein, ${ }^{48}$ Baer $^{49}$ Everett $^{50}$ and Freeman. ${ }^{51}$ Already then the results were controversial. Using a hot quartz contact lamp as UVB source Epstein et al tested 25 patients (21 SLE; 4 DLE). Nine patients had a history of photosensitivity and of these five developed local erythema persisting up to three months. Biopsies taken between two and six months after phototesting revealed hyperkeratosis, epidermal atrophy and cell destruction. Although not discussed in the paper, it is interesting that the follow-up of these patients must have been several weeks. It is now known that LE skin lesions typically occur after two to three weeks. In the report no reactions were noticed with wavelengths longer than $320 \mathrm{~nm}$. Baer and Harber noted that UVB radiation may cause systemic exacerbation in patients with subacute LE. They tested 29 patients $(23 \times$ DLE; $5 \times$ SLE; $1 \times$ subacute LE) using a bank of four fluorescent sunlamps having a continuous emission spectrum between 280 and $320 \mathrm{~nm}$. No differences of the erythema response compared to controls were noted. Only the patient with subacute LE developed a markedly decreased erythema threshold followed by persistent erythema. From these results they concluded that UV radiation is a trigger factor in a small number of LE patients, furthermore, it may induce systemic disease. One of the reasons for the lack of positive test results may be the fact that they only studied patients after $24 \mathrm{~h}$ and one week, thereby possibly missing the skin lesions appearing after two to three weeks. In another test series Freeman et $a l^{51}$ found that 8/10 DLE patients have positive reactions at $300 \mathrm{~nm}$, but none of five LE patients taking quinacrine could be provoked. No reactions were observed using the wavelengths $340,360,400$ or $500 \mathrm{~nm}$. However, again here problems arise concerning interpretation of data, since different energy doses were applied and higher energy doses of UVA than UVB are normally needed to induce photobiologically relevant reactions. Other investigations with the aim of finding the relevant wavelength for the induction of LE skin lesions were undertaken by Cripps and Rankin $^{52}$ in vivo and Emerit and Michelson in vitro. ${ }^{53}$ Cripps and Rankin observed that long-lasting erythema could be induced in LE patients by radiation with a range from 250 to $330 \mathrm{~nm}$, but not wavelengths higher than that. Emerit and Michelson detected that lymphocytes derived from SLE patients were sensitive to UVA radiation ( 360 to $400 \mathrm{~nm}$ ) in vitro.

In an attempt to use in vivo photosensitivity tests to investigate the action of drugs Lester $e t$ al studied the role of hydroxychloroquine sulfate, methylprednisolone sodium succinate and methotrexate in blocking light induced skin reactions. ${ }^{54}$ They tested 64 patients with various photosensitive disorders such as polymorphic light eruption (29 patients), systemic (5 patients) and cutaneous LE (9 patients). Totally $21 / 29$, $4 / 5$ and $4 / 9$ showed photoprovocation. In a group of selected patients they found that intradermally applied hydroxychloroquine blocked the reaction in five of seven patients. They discussed a possible association of positive antinuclear antibodies and positive test reaction. Moreover, Gilliam and Sontheimer were able to describe a separate form of $\mathrm{LE}$, the subacute cutaneous LE (SCLE), a very photosensitive disease, differing from SLE and DLE and associated with the presence of anti-Ro antibodies. ${ }^{4}$ These antibodies later attracted much interest. It was observed that Ro antigens were expressed on the surface of keratinocytes following UV radiation, thereby possibly provoking antibody dependent cell cytotoxicity. ${ }^{55}$ The group of Rosen showed elegantly in their study that these antigens were expressed during a process called apoptosis. ${ }^{56,57}$

\section{Phototest procedure}

Phototesting is a tool for diagnosis, documentation, identification of photosensitizers (photopatch test), therapy and investigation of pathophysiologically relevant factors. It should be carried out in patients with suspected hypersensitivity to light, for example solar urticaria, polymorphic light eruption, photoallergy, phototoxicity, lupus erythematosus or other autoimmune disorders. ${ }^{58}$

As a light source monochromatic light, metal halide lamps or a source equipped with fluorescent bulbs can be applied. Usually UVB and UVA radiation is used for testing photosensitivity of LE patients, however, certain photosensitive disorders such as solar urticaria may also require testing with visible light. Since sensitivity to UV radiation differs, testing the minimal 
erythema dose (MED) is necessary to make data comparable. The MED is defined as the minimal erythema occuring at a certain dose of UV radiation, usually UVB. ${ }^{59}$ MED depends on the wavelength and individual skin sensitivity. As a general rule, the lower the wavelength the lower the amount of energy doses necessary for the induction of one MED. The mean MED is $0.1( \pm 0.03) \mathrm{J} / \mathrm{cm}^{2}$ at $300 \mathrm{~nm} .{ }^{60}$ UVB has the highest relative effectiveness in the induction of erythema and late tanning after 12-24h. Also UVA may provoke erythema after $1-2 \mathrm{~h}$ with a maximum around 6-12 h, however, 500-1000 times higher doses are necessary compared to UVB. Physiologically, this is compensated by the fact that sun light, for example in Europe, contains nine times more UVA than UVB radiation. UVA causes immediate pigment darkening (IPD) depending on the dose $\left(5-20 \mathrm{~J} / \mathrm{cm}^{2}\right.$ at 320 $340 \mathrm{~nm}$ ), probably by induction of oxidative processes. It also induces de novo synthesis of pigment after $15-20 \mathrm{~h}$. The dose for IPD is $19( \pm 4.6) \mathrm{J} / \mathrm{cm}^{2}{ }^{60}$ Combination of UVA and UVB causes photoaugmentation and persistent pigmentation.

Usually the non-sunexposed, not affected areas of the back or the lower arms are used for phototesting in LE patients. ${ }^{12}$ Other parts of the skin may not react to the same extent probably due to thickness of the epidermal horny layers, vascularization, presence of antigen and distribution of antigen-presenting cells. ${ }^{12,61}$ For standardization it is important to use a defined test area. The size of this should be sufficiently large to provide reactions. As a recommendation it should cover $5 \times 8 \mathrm{~cm}^{2}{ }^{12,60}$ For the performance of the phototest we use $100 \mathrm{~J} / \mathrm{cm}^{2}$ UVA and 1.5 MED UVB on three following days. Single exposure to UV radiation may not induce positive reaction in all possible cases. The evaluation follows after $24 \mathrm{~h}, 48 \mathrm{~h}, 72 \mathrm{~h}$ as well as weekly until three or more weeks. Criteria for a positive photoprovocation are: (1) skin lesions resemble clinically LE, (2) slow development of skin lesions over several days or weeks and (3) confirmation of clinical diagnosis by histology. Typically, development of LE skin lesions has a latency of two weeks and may persist for months. Provocation of systemic disease in patients with SLE as a result of phototesting has not been observed. However, patients should be reminded of the fact that both hyperpigmentation, hypopigmentation and LE skin lesions may follow and persist for months leading to cosmetic problems.

\section{Results of phototests}

Results of reported photosensitivity in patients with cutaneous and systemic forms of LE often differ between various groups (Table 2). Several factors are responsible, for example definition of photosensitivity by the investigator, form of questioning, genetic background of the studied population and environmental factors. An additional factor might be the age at onset of disease and subjective photosensitivity as observed in our study of 189 LE patients (Table 3 ). Mainly patients under the age of 40 years reported photosensitivity.

In an attempt to standardize photosensitive disorders phototesting procedures were elaborated. Lehmann et al investigated MED and IPD in LE patients, since activation of skin lesions may be due to an enhanced response already to lower doses of UV radiation, however, no differences of MED or IPD were found ${ }^{60}$ Positive reactions after phototesting were observed to varying percentages in LE patients with cutaneous and systemic forms in our study (Table 4). Most of the patients with positive test results were provoked by UVB radiation. UVA induction of skin lesions was only found in patients with SCLE, SLE or LET. Also here, differences were

Table 2 Reported photosensitivity

\begin{tabular}{lll}
\hline Disease & Reported photosensitivity (\%) & Reference \\
\hline DLE & 0 & \\
& 74 & {$[76]$} \\
& 91 & {$[10]$} \\
SCLE & 52 & {$[61]$} \\
& 85 & {$[4]$} \\
& 90 & {$[77]$} \\
SLE & 6 & {$[78]$} \\
& 43 & {$[79]$} \\
& 61 & {$[2]$} \\
& & {$[80]$} \\
\hline
\end{tabular}

Table 3 Photosensitivity and age at disease onset

\begin{tabular}{llllll}
\hline & \multicolumn{2}{c}{ Under age $40 y$} & & \multicolumn{2}{c}{ Over age $40 y$} \\
\cline { 2 - 3 } & Subjective photosensitivity (\%) & Positive photoprovocation (\%) & & Subjective photosensitivity (\%) & Positive photoprovocation (\%) \\
\hline DLE & 31 & 36 & 12 & 40 & 0 \\
SCLE & 60 & 58 & 59 & 17 & 17 \\
SLE & 45 & 50 & 55 & \\
\hline
\end{tabular}


Table 4 Photosensitivity and UV radiation

\begin{tabular}{llllll}
\hline & & \multicolumn{3}{c}{ Positive phototest } \\
\cline { 3 - 6 } & Reported photosensitivity (\%) & All patients (\%) & UVA (\%) & UVB (\%) & UVA + UVB (\%) \\
\hline DLE & 25 & 39 & 0 & 25 & 25 \\
SCLE & 49 & 50 & 5 & 35 & 25 \\
SLE & 48 & 40 & 20 & 25 & 25 \\
\hline
\end{tabular}

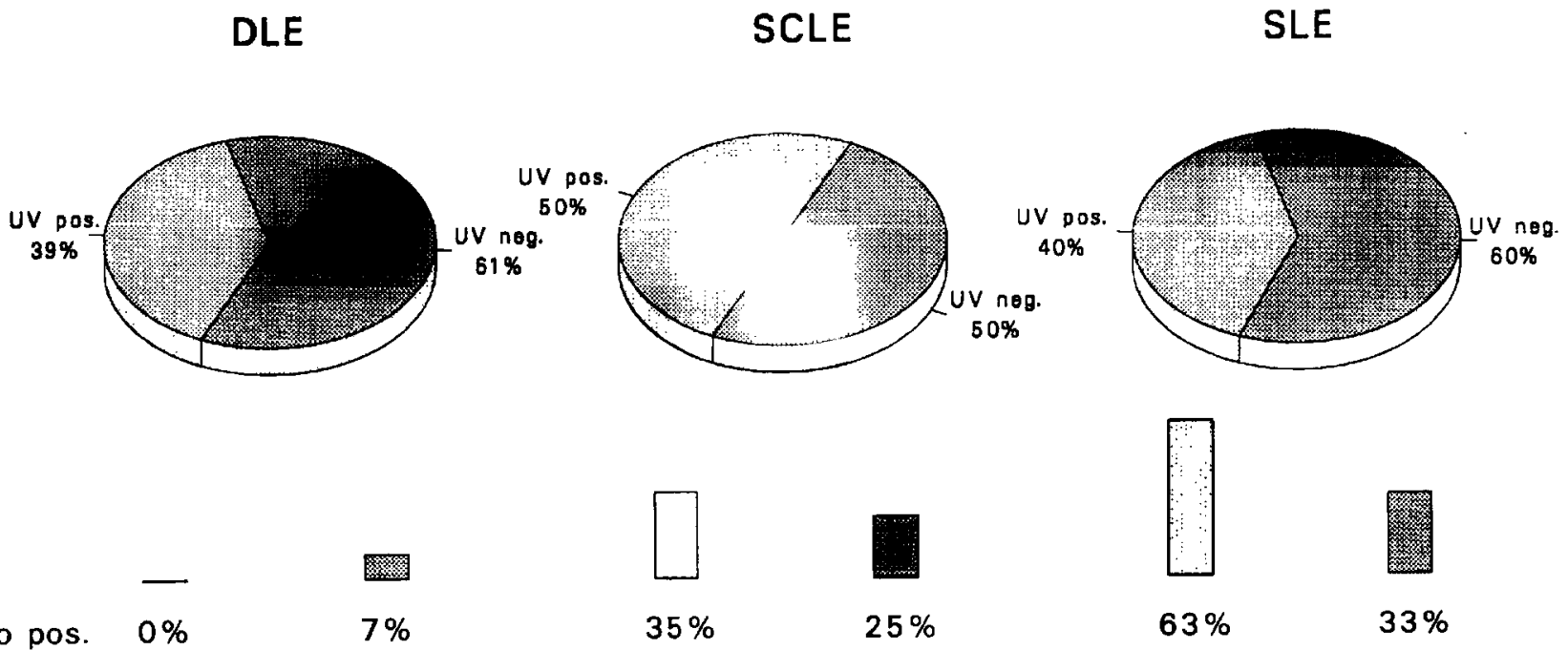

anti-Ro pos. $0 \%$

$7 \%$

Figure 1 Comparison of phototest results. Patients with DLE $(n=28)$, SCLE $(n=20)$ SLE $(n=20)$ were tested according to the protocol by Lehmann et $a l^{60}$ Positive and negative results were correlated with anti-Ro antibodies.

found due to the age of the patient at onset of disease (Table 3). Further investigations of immunologic parameters in phototested patients point to an association of positive phototest results and the finding of Ro antibodies (Figure 1). Therefore phototesting may help to subclassify patients in order to find genetic and immunologic factors associated with photosensitivity in the future. Genetic variance of the TNF genes and of putative genetic differences in the UV-stress response (NF- $k \mathrm{~B})$ represent good candidates.

Unfortunately test protocols vary between different groups making comparison of test results often difficult (Table 1). Varying factors are the light source used, the energy dose, wavelength, development of heat during radiation, time points of provocation and evaluation, location and size of test area. Furthermore, classification of positive reactions may be difficult, since persistent erythema may develop, which despite histological investigation is difficult to interpret. Kind and coworkers could demonstrate that the histopathology of early UV-induced lesions (up to ten days) in patients with cutaneous and systemic forms of LE shows unspecific changes such as superficial perivascular lymphocytic infiltrates, whereas late UV-induced lesions (more than ten days) were characterized by parakeratosis, few necrotic basal keratinocytes as well as vacuolar degeneration of the dermoepidermal zone. ${ }^{12}$ Immunohistochemistry of early lesions revealed no significantly altered expression of HLA-DR molecules, $\mathrm{CD}^{+}$and $\mathrm{CD}^{+}$ $T$-cells, whereas the infiltrate of late UV-induced lesions mainly consisted of CD4 ${ }^{+} \mathrm{T}$-cells in DLE and $\mathrm{CD}^{+} \mathrm{T}$-cells in SCLE. ${ }^{12}$ It is so far unclear, why skin lesions cannot always be reproduced at the same test area. ${ }^{62}$ An intriguing point is also the question why phototesting is not positive in $100 \%$ of LE patients, thus providing indirect evidence for variant parameters in the pathophysiology of LE and a variant threshold of inducibility.

\section{Photoprotection}

Tanning is fashionable,$^{63}$ however, besides photoageing UV radiation is a trigger factor for LE. Consequent protection against UV radiation is there- 
fore necessary. In principal two possibilities exist, topical or systemic protection

Topical protection against UV rays can be achieved by avoiding sun light and using sunblockers. Hat, clothes, umbrella and other physical factors provide only limited protection against UV radiation. Also the general belief that clouds hinder UV radiation from reaching the earth is wrong and tempts patients to stay out longer. ${ }^{66}$ Window glass only blocks UVB, but not UVA radiation and surfaces of sand and water may reflect sun rays thereby intensifying direct and indirect UV radiation. Therefore, physical protection cannot be sufficient in the photoprotection of LE patients.

Sunblockers or sunscreens are topically used preparations that reduce local UV action. These can be subdivided into products using UV filters on a physical or on a chemical background. Examples for physical sunblocking agents are titanium dioxide, talcum or zinc oxide (UVB and UVA), and for chemical photoprotective products para-amino-benzoic acid (PABA) derivatives and benzophenones. ${ }^{64,65}$ Most chemical sunblockers contain a combination of different filters in order to block a higher percentage and broader range of UV rays.

Physical suncreens do not absorb UV rays, but rather reflect or disperse ${ }^{67}$ serving as shield against UVA and UVB radiation. Usually they are nonphotosensitizing, but may sometimes be unacceptable for patients, since they are partially visible. Furthermore, physical sunscreens are normally not easily washed off, moreover, offer limited protection over time, since they melt with the heat of the sun. Chemical sunblocking agents consist of chemical light-absorbing molecules, they are efficient in blocking UVB and shorter UVA rays. One of the first sunprotective chemicals was benzyl cinnamate and benzyl salicylate, later followed by para-aminobenzoic acid (PABA) and esters, benzophenones and ethylhexyl-para-methoxy cinnamate. ${ }^{64,67}$ Chemical sunblockers penetrate into the stratum corneum, stay attached to proteins and therefore are not easily washed off. ${ }^{64,65}$ On the other hand, chemical sunblockers have a higher risk for the development of photoallergic or phototoxic reactions. ${ }^{58,68}$

Effectiveness of sunblockers is expressed as the sun/ultraviolet protection factor (SPF/UPF), which is defined as the ratio of the MED of sun-protected skin divided by the MED of non-sunprotected skin. Filters with SPF of 15 protect from more than $90 \%$ of UV radiation. The protection against longer UVA waves may not be properly fulfilled. Furthermore, individual factors such as sweating, skin thickness and application of the product may lead to differences. ${ }^{64}$ Photoprotection may also be achieved by systemic medication with drugs such as chloroquine, hydroxy- chloroquine, vitamins ( $\mathrm{C}$ and $\mathrm{E})$ and retinoids. Their exact mode of action is still unknown, however, they may act as antioxidants, thereby interacting with the formation of ROI, block local and systemic immune reactions and indirectly hinder UV radiation from induction of skin lesions. ${ }^{64,69-72}$

\section{Conclusions}

Standardized phototest procedures are available for the diagnosis and classification of photosensitive disorders. Phototesting is a valid model for the identification of relevant pathogenetic factors in the development of lupus erythematosus. Further experimental studies are necessary to elucidate these factors molecularly.

\section{References}

1 Gilliam JN, Sontheimer RD. Skin manifestations of SLE. Clin Rheum Dis 1981; 8: 207-218.

2 Tan EM, Cohen AS, Fries JF. The 1982 revised criteria for the classification of systemic lupus erythematosus. Arthritis Rheum 1982; 25: $1271-1277$

3 Gilliam JN, Sontheimer RD. Distinctive cutaneous subsets in the spectrum of lupus erythematosus. $J$ Am Acad Dermatol 1981; 4: 471475

4 Sontheimer RD, Thomas JR, Gilliam JN. Subacute cutaneous lupus erythematosus. Arch Dermatol 1979; 115: 1409-1415.

5 David-Bajar KM. Subacute cutaneous lupus erythematosus. $J$ Invest Dermatol 1993; 100: 2S-8S.

6 Kind P, Lakomek HJ, Goerz G. Kutaner Lupus erythematodes. Die Internistische Welt 1987; 4: 92-99.

7 Amold HL. Lupus erythematosus profundus (Kaposi-Irgang). Arch Dermatol Syph 1948; 196: 196-203.

8 Kind P, Goerz G. Der kutane Lupus erythematodes. In: Macher E, Knop J, Bröcker EB (eds). Jahrbuch der Dermatologie. Dr. Biermann Verlagsgesellschaft, Münster 1988, pp 88-103.

9 Tuffanelli DL. Discoid lupus erythematosus. Clin Rheum Dis 1985; 8 327-341.

10 O'Loughlin S, Schroeter AL, Jordon RE. A study of lupus erythematosus with particular reference to generalized discoid lupus. Br J Dermatol 1978; 99: 1-11.

11 Kind P, Lehmann P. Photobiologie des Lupus erythematodes. Hautarzt 1990; 41: 66-71.

12 Kind P, Lehmann P, Plewig G. Phototesting in lupus erythematosus. $J$ Invest Dermatol 1993; 100: 53S-7S

13 Becker MM, Wang Z. Origin of ultraviolet damage in DNA. J Mol Biol 1989; 210: $429-438$

14 Peak MJ, Peak JG, Carnes BA. Induction of direct and indirect singlestrand breaks in human DNA by far- and near-ultraviolet radiations: action spectrum and mechanisms. Photochem Photobiol 1987; 45 381-387

15 Baeuerle PA, Henkel T. Function and activation of NF- $k$ B in the immune system. Annu Rev Immunol 1994; 12: 141-179.

16 Golan et al. Solar ultraviolet radiation induces enhanced accumulation of oxygen radicals in murine SLE-derived splenocytes in vitro. Lupus 1994; 3: $103-106$.

17 Sauder DN, Wong D, Laskin C. Epidermal cytokines in murine lupus. $J$ Invest Dermatol 1993; 100: 42S-46S.

18 Furukawa F, Lyon MB, Norris DA. Susceptible cytotoxicity to 
ultraviolet B light in fibroblasts and keratinocytes cultured from autoimmune-prone $\mathrm{MRL} / \mathrm{Mp}-\mathrm{lpr} / \mathrm{pr}$ mice. Clin Immunol Immunopathol 1989; 52: 460-472.

19 Furukawa F, Kanauchi H, Imamura S. Susceptibility to UVB light in cultured keratinocytes of cutaneous lupus erythematosus. Dermatology 1994; 189: 18S-23S.

20 Messer G, Weiss EH, Baeuerle PA. Tumor necrosis factor $\beta$ (TNF- $\beta$ ) induces binding of the NF- $k \mathrm{~B}$ transcription factor to a high-affinity $k \mathrm{~B}$ element in the TNF- $\beta$ promoter. Cytokine 1990; 2: 389-397.

21 Bazzoni $\mathrm{F}$ et al. Analysis of tumor necrosis factor promoter responses to ultraviolet light. $J$ Clin Invest 1994; 93: 5662 .

22 Ansel J et al. Cytokine modulation of keratinocyte cytokines. $J$ Invest Dermatol 1990; 94: 101S-107S

23 Garmyn $\mathrm{M}$ et al. Effect of aging and habitual sun exposure on the genetic response of cultured human keratinocytes to solar-simulated irradiation. J Invest Dermatol 1992; 99: 743-748.

24 Sontheimer RD. Photoimmunology of lupus erythematosus and dermatomyositis: a speculative review. Photochem Photobiol 1996; 63: $583-594$

25 Norris DA. Pathomechanisms of photosensitive lupus erythematosus. $J$ Invest Dermato! 1993; 100: 58S 68S.

26 Hruza LL, Pentland AP. Mechanism of UV-induced inflammation. $J$ Invest Dermatol 1993; 100: 35S -41S

27 Streilein JW. Sunlight and skin-associated lymphoid tissues (SALT): If UVB is the trigger and TNF $\alpha$ is its mediator, what is the message. $J$ Invest Dermatol 1993; 100: 47S-52S.

28 Bielsa et al. Histopathologic findings in cutaneous lupus erythematosus. Arch Dermatol 1994; 130: 54-58.

29 de Jong EMGJ, van Erp PEJ, Ruiter DJ, van de Kerkhof PCM Immunohistochemical detection of proliferation and differentiation in discoid lupus erythematosus. $J$ Am Acad Dermatol 1991; 25: 1032 1038.

30 Provost TT, Reichlin M. Immunopathologic studies of cutaneous lupus erythematosus. J Clin Immunol 1988; 8: 223-233.

31 Kind P, Goerz G. Histologie des Lupus erythematodes. In: Holzmann H (ed). Dermatologie und Rheuma. Springer: Berlin, 1987, pp 278283.

32 Watanabe T, Tsuchida T. Classification of lupus erythematosus based upon cutaneous manifestations. Dermatology 1995; 190: 277-283.

33 Bangert JL, Freeman RG, Sontheimer RD, Gilliam JN. Subacute cutaneous lupus erythematosus and discoid lupus erythematosus. Arch Dermatol 1984; 120: 332-337.

34 Ansel JC et al. Effects of UV radiation on autoimmune strains of mice: increased mortality and accelerated autoimmunity in BXSB male mice. J Invest Dermatol 1985; 85: 181-186.

35 Walchner M, Leib-Mösch C, Messer G, Kind P. Endogene retrovirale Sequenzen als Faktor in der Pathogenese des systemischen Lupus erythematodes. Hautarzt 1996; 47: 502-509.

36 McGrath H, Bak E, Michalski JP. Ultraviolet-A light prolongs survival and improves function in (New Zealand black $\times$ New Zealand White) F1 hybrid mice. Arthritis Rheum 1987; 30: 557-561.

37 Cazenave A. Lupus erythemateux. Ann Mal Peau Syph 1851; 3: 298 303.

38 Kaposi MK. Neue Beiträge zur Kenntnis des Lupus erythematodes. Arch Dermatol Syph 1872; 1: 36-78.

39 Hutchinson J. Harveian lectures on lupus. Br J Med 1888; 1: 113-118.

40 MacLeod JMH. Lupus erythematosus. Some observations on its etiology. Arch Dermatol Syph 1924; 9: 1-12.

41 Freund $H$. Inwiefern ist der lupus erythematodes von allgemeinen Faktoren abhängig. Dermatol Wschr 1929; 30: 1939-1946.

42 Fuhs E. Lupus erythematodes subacutus mit ausgesprochener Überempfindlichkeit gegen Quarzlicht. Zentrbl Hautkr 1929; 30: 308-309.

43 Kesten BM, Slatkin M. Diseases related to light sensitivity. Arch Dermatol 1953; 67: 284-301.

44 Jesionek A. Richtlinien der modernen Lichttherapie. Strahlentherapie 1916; 7: 41-65.

45 Davidson AM. Quinine bisulfate as desensitizing agent in the treatment of lupus erythematosus. Arch Dermatol Syph 1938; 37: 247-253.

46 Zarafonetes CJD, Greken RH, Curtis AC. Further studies on treatment of lupus erythematosus with sodium-para-aminobenzoate. $J$ Invest Dermatol 1948; 11: 359-381.

47 Garzon R, Ferraris L, Cancio C. Contribucion el estudio experimental del lupus eritematoso. Rev Argent Dermatol 1949; 33: 106-118.
48 Epstein JH, Tuffanelli DL, Dubois EL. Light sensitivity and lupus erythematosus. Arch Dermatol 1965; 91: 483-485.

49 Baer RL, Harber LC. Photobiology of lupus erythematosus. Arch Dermatol 1965; 92: 124-128.

50 Everett MA, Olson RL. Response of cutaneous lupus erythematosus to ultraviolet light. $J$ Invest Dermatol 1965 ; 44: 133-139.

51 Freeman RG, Knox JM, Owens DW. Cutaneous lesions of lupus erythematosus induced by monochromatic light. Arch Dermatol 1969; 100: $677-682$

52 Cripps DJ, Rankin J. Action spectra of lupus erythematosus and experimental immunofluorescence. Arch Dermatol 1973; 107: 563567.

53 Emerit I, Michelson M. Mechanism of photosensitivity in systemic lupus erythematosus patients. Proc Natl Acad Sci USA 1981; 78: 25372540.

54 Lester RS, Burnham TK, Fine G, Murray K. Immunologic concepts of light reactions in lupus erythematosus and polymorphous light eruptions. Arch Dermatol 1967; 96: 1-10.

55 LeFeber WP et al. Ultraviolet light induces binding of antibodies to selected nuclear antigens on cultured human keratinocytes. $J$ Clin Invest 1984; 74: 1545-1551.

56 Casciola-Rosen LA, Anhalt G, Rosen A. Autoantigens targeted in systemic lupus erythematosus are clustered in two populations of surface structures on apoptotic keratinocytes. J Exp Med 1994; 179: 1317-1330.

57 Rosen A, Casciola-Rosen L, Ahearn J. Novel packages of viral and self-antigens are generated during apoptosis. $J \operatorname{Exp}$ Med 1995; 181: $1557-1561$.

58 Hölzle E, Plewig GG, Lehmann P. Photodermatoses: diagnostic procedures and their interpretation. Photodermatology 1987; 4: 109-114.

59 Wucherpfennig V. Zur Messung und Bemessung des Ultraviolett. Klin Wschr 1942; 21: 926-930.

60 Lehmann $\mathrm{P}$ et al. Experimental reproduction of skin lesions in lupus erythematosus. J Am Acad Dermatol 1990; 22: 181-187.

61 van Weelden H, Velthuis PJ, Baart de la Faille H. Light-induced skin lesions in lupus erythematosus: photobiological studies. Arch Derm Res 1989; 281: 470-474.

62 Higuchi D, Ogura Y, Watanabe H, Takiuchi I. Experimental production of DLE lesion with a single exposure to UVB (2.7 MEDs) radiation. $J$ Dermatol 1991; 18: 545-548.

63 George PM, Kuskowski M, Schmidt C. Trends in photoprotection in American fashion magazines, 1983-1993. J Am Acad Dermatol 1996; 34: 424428 .

64 Pathak MD. Sunscreens: Topical and systemic approaches for protection of human skin against harmful effects of solar radiation. $J$ Am Acad Dermatol 1982; 7: 285-312.

65 Taylor CR, Stern RS, Leyden JJ, Gilchrest BA. Photoageing/ photodamage and photoprotection. I Am Acad Dermatol 1990; 22: $1-15$.

66 Owens DW, Knox JM, Hudson HT, Troll D. Influence of wind on ultraviolet injury. Arch Dermatol 1974; 109: 200-201.

67 Algra RJ, Knox JM. Topical photoprotective agents. Int J Dermatol $1978 ; 17: 628-633$

68 Fisher AA. Sunscreen dermatitis due to glyceryl PABA: significance of cross reactions to this PABA ester. Cutis 1976; 18: 495-496.

69 Allison JL, O'Brien RL, Hahn FE. DNA reactions with chloroquine. Science 1965; 149: 1111-1113.

70 Dubois EL. Antimalarials in the management of discoid and systemic lupus erythematosus. Semin Arthr 1978; 8: 33-51.

71 Wallace DJ, Linker-Israeli M, Metzger AL, Stecher VJ. The relevance of antimalarial therapy with regard to thrombosis, hypercholesterolemia and cytokines in SLE. Lupus 1993; 2: 13S-15S.

72 Fisher GJ et al. Molecular basis of sun-induced ageing and retinoid antagonism. Nature 1996; 379: 335-359.

73 Berk SH, Blank H. Ultraviolet light and cytoplasmic tubules in lupus erythematosus. Arch Dermatol 1974; 109: $364-366$.

74 Beutner EH et al. Studies on criteria of the European Academy of Dermatology and Venerology for the classification of cutaneous lupus erythematosus. Int $J$ Dermatol 30: 411-417, published erratum 1991 30557.

75 Nived O, Johansen PB, Sturfelt G. Standardized ultraviolet-A exposure provokes skin reaction in systemic lupus erythematosus. Lupus 1993; 2: $247-250$. 
174

76 Davis P, Atkins B, Hughes GRV. Antibodies to native DNA in discoid lupus erythematosus. Br J Dermatol 1974; 91: 175-181.

77 Dubois EL. Lupus Erythematosus. 2nd ed, University of Southern California Press: Los Angeles, 1974.

78 Callen JP, Klein J. Subacute cutaneous lupus erythematosus: Clinical, serologic, immunogenetic, and therapeutic considerations in seventytwo patients. Arthritis Rheum 1988; 31: 1007-1013.
79 Mody GM et al. High mortality with systemic lupus erythematosus in hospitalized African Blacks. Br J Rheum 1994; 33: 11511153.

80 Pande I et al. Analysis of clinical and laboratory profile in Indian childhood systemic lupus erythematosus and its comparison with SLE in adults. Lupus 1993; 2: 83-87. 